\title{
İş ve Özel Hayat Arasındaki Sınırların Belirsizleşmesi
}

\author{
The Obscurity of the Border Line Between the Areas of Work and Private Life
}

\section{Elife KART*}

Özet: Günümüzde, küreselleşen sermaye ve iletişim teknolojilerindeki gelişme, küresel boyutta iş organizasyonunun yeni biçimlerinin oluşturulmasında etkili olmaktadır. İş organizasyonunun esnek biçimleri, çalışma mekânını ve zamanını belirsiz kılarak, özel alana ilişkin olan dinamikleri, iş sürecinde, verimlilik koşullarının süresiz üretildiği alanlara dönüştürmektedir. Sermaye, siyasal, ekonomik ve kültürel içerikli bütün alanlarda olduğu gibi, özel alan üzerinde de, ideolojik ve kültürel kontrol gücünü genişletebilmektedir. Özellikle esnek üretim süreci içerisinde yer alan çalışanlar üzerinde farklı türden denetim ve kontrol mekanizmalarının geliştirilmesi, iş ve özel alan arasındaki ilişkilerin yapısını değiştiren bir durum yaratmaktadır. Bu durum, çalışanları, özel yaşam alanı ile iş alanını bütünleştiren dinamikleri üretmeye yöneltmektedir. Ayrıca, iş ve özel alan arasındaki sınırların belirsiz hale getirilmesi, çalışanlar açısından yeni sorunlar ve yeni çatışmalar üretmektedir. Esneklik ilkesiyle karakterize edilen iş organizasyonundaki yeni biçimler, çalışanı, sermayenin öngördüğü üretkenlik ve verimlilik ölçütlerini gerçekleştirme zorunluluğuyla karşı karşıya bırakmakta, iş ve özel alan arasında ikileme düşürmekte, zaman ve mekân sıkışması olgusunu yaratmaktadır. İş ve özel alan arasında, zamansal ve mekânsal anlamda sıkışma, çalışanlar açısından, fiziksel, psikolojik ve sosyal farklı türden birçok sorunun kaynağını oluşturmaktadır.

Anahtar Sözcükler: Esneklik, Çalışma süresinin belirsizliği, İşin mekânsızlaştırılması, özel hayat

Abstract: Today developments taking place in globalized capital and in communication technologies are seriously affecting the emerging forms of work organization worldwide. Increasing flexibility in the organization of working hours and work space are not only changing the dynamics of private life into an area where efforts towards increased productivity are on-going, but is, at the same time, rendering the workplace itself ambiguous. As in all fields having a political, economic and cultural nature, capital has the ability to expand its ideological and cultural control over private areas of life. Imposing various forms of control and supervision mechanisms upon workers leads to changes in the pattern of relationships between work and the private area, and pushes the worker to produce a dynamic in which the field of private life becomes integrated with that of the job. In addition, as the dividing line between work and private life becomes increasingly vague, the worker faces new problems and new areas of conflict. The new forms of work organization characterized by the principle of flexibility, force the worker to accept that both productivity and efficiency are directed by capital and lead him/her into a dilemma between the field of work and his/her private life. The consequent pressure experienced by the worker in terms of time and place is becoming the root of a variety of physical, psychological and social problems.

Keywords: Flexibility, Ambiguity of Working Hours, Reduction of Work Space, Private life

Küresel ekonomik koşullar ve istihdam yapısındaki yenilikler, çalışanlar açısından çarpıcı düzenlemeleri beraberinde getirmekte ve çalışanlar üzerinde yeni kontrol biçimleri ortaya çıkarmaktadır. Son yıllarda “iş”, “işgücü” üzerine yapılan çalışmaların, esnek çalışma sistemlerine

\footnotetext{
* Yrd. Doç. Dr., Akdeniz Üniversitesi, Edebiyat Fakültesi, Sosyoloji Bölümü, Antalya, elifekart@akdeniz.edu.tr
} 
odaklandıkları, söz konusu çalışma sistemlerinden kaynaklı sonuçlar üzerinde durdukları görülmektedir. Bu durum, çalışma koşullarının giderek esnekleşmesine, çalışma alanı ve süresinin belirsiz kılınması, özel yaşamın, işin gerektirdiği bir biçimde geçmiştekinden farklı biçimlerde yeniden dönüşüme zorlanması ve çalışanın özel yaşamında, farklı türden sorunların oluşmasına kaynaklık eden, geçmişten farklı parametreleri ortaya çıkarmaktadır. Sermaye ilişkilerinin gerektirdiği uygulamalar, çalışanların özel yaşamlarına nüfuz ederek, sermayeyi farklı boyutlarda yeniden üretmektedir. Çalışanların özel yaşamını ve ilişki ağlarını etkisi altına alan bu süreç, çalışanların, sermayenin öngördüğü bir biçimde, özel yaşam alanlarını dönüştürmelerine neden olmaktadır.

Çalışanlar açısından işi mekânsızlaştıran, iş ve özel yaşam arasındaki sınırları belirsiz hale sokan bu durum, özel yaşam alanına bağlı değerler sisteminin, organizasyonların ön gördüğü kurallar çerçevesinde yeniden şekillendirilmesi anlamına gelmektedir ve bu iş ve özel alan arasında tanımlanmış sınırları zayıflatmaktadır. Özel alanın "iş" için yeniden tanımlanma ve konumlandırılma süreci, yarattığı etkilere bağlı olarak, çalışanlar açısından farklı türden çatışmaların ve gerginliklerin belirginleşmesine neden olmaktadır. Özel alan, artık sermayenin beklentileriyle uyumlu, iş merkezli etkileşimin hâkim olduğu bir ortama dönüşmektedir. $\mathrm{Bu}$ ortamı meydana çıkaran temel dinamik ise, işin belli bir mekâna bağlı olmaksızın gerçekleştirilebilmesine olanak tanıyan, çalışma koşullarındaki niteliksel değişikliklerdir.

\section{Çalışma Koşullarının Değişen Niteliği ve İşin Mekânsızlaş(tırıl)ması}

Sermayenin küreselleşmesiyle birlikte, devletin işgücü açısından korumacı işlevinin giderek azalması, işgücünü, bireysel temelde sermayenin politikalarına bağımlı hale getirmektedir. Söz konusu sürecin, iş gücü piyasası üzerinde ulus ötesi dinamiklerin gücünü belirleyici kılması, sermayenin, kendi iş verimliliğini arttırma odaklı yönetim anlayışlarını benimseme eğilimlerini arttırmakta ve çalışanlar açısından 'iş güvencesizliği” nin koşullarını üretmektedir. Özellikle, ekonominin en hızlı büyüyen sektörü olan, hizmet sektörünün, "yirmi dört saat ve yedi gün" çalışma ekonomisi olarak tanımlandığı günümüzde (Edwards, \& Wajcman, 2005, 49), organizasyonlar, rekabet koşullarına uyum sağlayabilmek için esnek çalışma sistemlerine odaklanmaktadır.

Organizasyonların, verimlilik politikalarını üretmek ve çalışanların sermayenin amaçları ile bütünleşmelerini sağlamak hedefli uygulamalara yöneldiklerini, çalışma alanının ve süresinin belirsiz hale getirilmesinden anlamak mümkündür. Özel yaşam, sermayenin beklentileri bağlamında, verimlilik koşullarının gerçekleştirildiği, ekonomik rasyonalite güdümlü bir alana dönüşmektedir. "Esneklik" ve "kuralsızlık" ilkelerinin, iş gücü piyasası üzerinde uygulama alanlarına kavuşması, çalışanı, iş güvencesini sağlayabilmek amacıyla, özel yaşamını iş için yeniden dönüştürme zorunluluğuyla karşı karşıya bırakmaktadır. Örneğin, Rowntree Vakfı'nın, bini aşkın aile ile ilgili hazırladığı raporda, geleneksel akşam yemeklerine ve küçük aile gezilerine dair küçük bir iz bulunamamıştır (Edwards, \& Wajcman, 2005, 49). Bu durum sermayenin kendini üretme sürecine katkıda bulunurken, diğer taraftan, denetim ve kontrol mekanizmalar1nın çeşitli biçimlerde, çalışan üzerinden kendini yeniden nasıl ürettiğini de ortaya koymaktadır.

Söz konusu durum, çalışanın, organizasyonların amaçları çerçevesinde, sahip oldukları sosyal, bilişsel ve duygusal tüm niteliklerini 'iş' için, iş dışındaki alanlarında bile, en etkin biçimde verimliliğe dönüştürmesine neden olmaktadır. Çünkü yeni ekonominin rasyonalitesi, çalışanı bir "sermaye" olarak, kendi ekonomik amaçları doğrultusunda kullanabildiği ölçüde değerli görebilmektedir (Gorz, 2001, 16). "Esneklik" ve "kuralsıllık" ilkelerinin yönlendirdiği çalışma koşullarının, çalışanın iş güvenliğini sürekli tehdit etmesi, çalışanı, sürekli artan verimlilik ölçütlerini karşılamak zorunda bırakmaktadır. Bu durum, "özel alan”1 ekonomik ve politik açıdan yeniden biçimlendirmektedir. "Özel alan"ın, organizasyonların hedefleriyle 
uyumlu kılınma çabası, “özel alan”'n yeni ekonominin aklı tarafindan, yönetilen ve kontrol edilen özelliğine işaret etmektedir.

Çalışma ilişkilerinde yaşanan bu dönüşümler, günümüzde, iş ve aile arasındaki alanların giderek yakınlaşmaya başlamasından, hem erkek hem de kadının eve kazanç getirmesinden, işgücüne katılım açısından kadın ve erkeklerin oranının giderek yakınlaşmasından, (Kadın iş gücünün, erkek işgücüne \%10 göre, daha hızlı bir şekilde artmaya $\% 14$ devem ettiğini gösteren diğer bir çalışma için, bkz. Eva. E. Jacobs, Projections of Labor Force and Employment By Industry and Occupation, Handbook of U.S Labor Statistic, Employment, Earnings, Prices, Productivity, and Other Labor Data. Bernan Press, 2006) kadınların çalışma sektörüne katıl1mının giderek artmasından, aynı doğrultuda erkeklerde evle ilgili daha fazla sorumluluk sahibi olmaya başlamalarından gözlenebildiği gibi (Macdermid, 2005, 22), iş organizasyonunun yeni yönelimlerinde, kullanılan yöntem ve stratejilerde de ortaya çıkmaktadır. Bu durum, yeni ekonomik koşulların, işgücü piyasasında bireysel çalışma koşullarını üretmesinde belirginleşmektedir. Ücret ve sözleşme politikalarının bireysel temelde belirlenmesi, performansa bağlı ücret uygulamalarının gündeme gelmesi ve iş sözleşmelerinde atipik ya da standart dışı uygulamaların benimsenmesi gibi yöntemler, çalışanları, iş güvenliği açısından belirsizlik içerisine sürüklemekte ve söz konusu çalışma ilkeleri, çalışanlar açısından "güvencesizliğin krizi"ne yol açmaktadır (Toksöz, 1999, 5). Aynı zamanda, iş istikrarının giderek bozulması ve uzun süreli işin giderek azalması (Lambert, \& Waxman, 2005, 111) biçiminde karşımıza çıkan söz konusu uygulamalar, devletin sermaye lehine değişen işlevleri ile birlikte, uygulamaya koyulan politikalar aracılığıyla, çalışanı bireysel temelde yalnızlaştırarak, ideolojik temelde, sermayeyle işbirliğine zorlayan süreçleri yatmaktadır. Devletin söz konusu konumu ve uygulamaları, çalışanlar açısından istihdamı sınırlı bir hale getirmekte ve bu, çalışanlar arasında rekabetin koşullarını üreterek, birbirleriyle dayanışma duygularını da ortadan kaldırmaktadır.

Çalışma koşullarının söz konusu yönelimleri ile çalışanın işini kaybetme kaygılarının aynı çerçeve içerisinde birbirini tamamlayan bağımlı bir ilişkiye dönüşmesi, işi mekânsız hale getirerek, özel alanı sermayenin verimliliğine odaklı hale dönüştürmektedir. İş gücü açısından, hem zamanın, hem de mekânın kuralsızlaştırılmış (Sennett, 2005, 88) yapısını ortaya koyan bu durum, çalışanın kendini sürekli yenileme ve soyut çalışma kapasitesini geliştirmesini de zorunlu hale getirmektedir. Böylelikle, işgücünün fiziki ve psişik tüm yaşam alanları da kuşatılmış olmaktadır (Gorz, 2001, 58-118). Bu zorunluluk biçimi, çalışan özneden, kendisini işyerine giderek daha fazla vermesi, özel yaşam alanı için sakladığ 1 şeyler de dahil olmak üzere kişiliğinin bazı kaynaklarını gönüllü olarak iş yerine sunması, işyerinin onun için arzu nesnesi olması ve derindeki ben'ini ve yaratıcılığını işyerinin hizmetine koşmasını (Mendel, 2005, 244) gerektirmektedir. Sermaye ve çalışan arasındaki ilişkinin aldığı bu biçim, sermayenin, çalışanlar üzerinde tahakkümün ideolojik ve kültürel koşullarını nasıl ürettiğini de ortaya koymaktadır. Çalışanlar üzerinde oldukça etkili olan, tahakkümün bu bağlamda kurulması, yeni kontrol araçlarının işleyişine de dikkat çekmektedir. İş organizasyonunun yeni biçimlerinin "özerklik", "bireysel katılım" ve "kişisel inisiyatif" gibi yeni kontrol ve iktidar araçlarını içermesi, tahakkümün belirtilen içeriğini, çalışanlar açısından daha yıkıcı etkilere doğru genişletmektedir.

Çalışma koşulları üzerinde, kontrol araçlarının bu karmaş̧ı ve çeşitli etkileri, "iş"in klasik anlamından, yani "bireysel yaşam planı ömür boyu sürecek uğraşın çatısını oluşturmak" anlamından (Bauman, 1997, 100) uzaklaşarak, günümüzde "parçalanmışlık", "süreksizlik" ve "sonuçsalsızlık" biçiminde belirlenen (Bauman, 2001, 342), yapısından kaynaklanmaktadır. Yeni ekonomik koşulların, uzun vade olmaması mantığına dayanması (Sennett, 2005, 21), çalışan açısından, "işin sonlu, klsa süreli, geçici ve sözleşmesiz, hiçbir güvencesi olmayan, 'ikinci bir uyarıya kadar' süren konumlarda çalışma" (Bauman, 2005, 35) biçimindeki bir çalışma sürecine dönüşmektedir. 
Günümüzde, çalışan ve sermaye arasındaki ilişkinin, kısa ve zayıf bağlara dönüşen yapısı, işi, "düzenli bir etkinlik" ve "geleceği olan bir iş" şeklindeki konumlamalardan çıkarmakta, "yaşam boyu iş" biçimindeki algılama biçimlerinden uzaklaştırmaktadır. Söz konusu algılama biçimi, "iş güvencesizliği" kaygıları içerisinde hareket eden çalışanın, yeniden iş arama ve işi değiştirme yoğunluğunu arttırmaktadır (Wanberg, \& Mueller, \& Shi, 2001, 253). Bu durum, "işi " çalışanlar için, ekonomik anlamının dışında daha varoluşsal ve çalışanın sosyal, bilişsel ve psişik bütün niteliklerini kapsayan bir anlama ulaştırmaktadır. Çalışanlar açısından, bu politik ve ekonomik biçimlenişin deneyimlenmesi, ekonomik iktidarın, iş ortamını da aşarak, çalışanın, değerler ve ilişki örüntülerini içeren alanları üzerinde de etkili olduğunu ve yine bu alanlar üzerinde, dolaysız bir biçimde, kontrolünü sürdürdüğünü ortaya koymaktadır.

\section{Özel Yaşamın Kuşatılması}

İş organizasyonunun esneklik ilkesi üzerinden ürettiği istihdam ilişkilerinin belirsizlik ve kuralsızlık içeren dinamikleri, çalışanın bilişsel sosyal ve kişisel tüm niteliklerini iş için birer verimlilik aracına dönüştürmektedir. Çalışanın, sermayenin hesaplanabilir amaç-araç ilişkisi içinde, kendisinden beklenilen verimlilik koşulunu gerçekleştirme çabası, özel yaşamın önceliğini geriye itebilmektedir. Esnek çalışma koşullarının, işi giderek yoğunlaştıran yapısı, zaman ve mekânı esnek kılarak, kısmi bir özerklik içinde hareket eden çalışanın özel alanını, işin devam edilebildiği alanlara dönüştürmektedir. Çalışanın, kendisinden beklenilen ekonomik verimliliği gerçekleştirme zorunluluğu, özel yaşama ilişkin algılamalarını bozarak değiştirmektedir. Özel yaşam alanı, işin devamlılığının sürdüğü bir alana dönüşmektedir. Bu dönüşüm süreci üzerinde küresel ekonominin alt yapısını oluşturan, internet ve küresel bilgisayar ağlarının, üretim ve pazar yapılarını dönüştüren, itici ve dönüştürücü gücü önemli bir rol oynamaktadır. Küreselleşmenin teknoloji aracılığ 1 ile zamanı ve mesafeyi ortadan kaldırarak, dünya genelinde yaygınlaşması (Gray, 2006, 94), sermayenin kendini üretme çabalarına katkıda bulunurken, diğer taraftan, çalışanlar üzerinde, içsel bir denetim kurma gibi, yeni kontrol araçlarının uygulanmasına ilişkin pratikleri gündeme getirmektedir.

Giderek esnekleşen ekonomik yapılanma içerisinde, önemli bir işleve sahip olan yeni iletişim teknolojileri, özel yaşam ve çalışma alanını bütünleştirmede etkili bir boyut olarak karşımıza çıkmaktadır. Söz konusu teknolojiler, bireylerin haftanın yedi günü ve yirmi dört saat çalışmasını olanaklı hale getirmektedir. Bureau of Labor Statistics tarafindan yapılan araştırma sonuçlarına göre, erkek yöneticilerin \%40'ının, kadın yöneticilerin \%20'sinin haftada kırk dokuz saat ya da daha fazla çalıştığını (Kossek, \& Lambert, 2005, 7) ortaya koymaktadır. Güvensizliğin, esnekliğin ve belirsizliğin, bir arada olduğu, karşılıklı bağımlı çalışma fonksiyonlar1 ile karakterize edilen yeni ekonomi (Giga, \& Cooper, 2005, 434), yeni teknolojiler aracılığıyla, zaman ve mekan sınırlamalarını ortadan kaldırarak, yedi gün, yirmi dört saat her yerden ulaşılmayı ve ulaşabilmeyi mümkün kılmaktadır. Bu durum, profesyonel çalışanların, kendilerine ait zamanlarını iş ile ilgili aktivitelerle geçirmelerine neden olmaktadır. Teknoloji, verilen belirli bir zamana çok daha fazla etkinliğin sıkıştırılmasına yol açmaktadır (Milliken, \& Dunn-Jensen, 2005, 45). Özel yaşamın işin verimliliği için araçsallaştırılması, yeni iş organizasyonları açısından, işin daha etkili yapılması anlamlarını içermektedir ve bu özellik, çalışanlar açısından olumsuz süreçleri tetikleyen bir duruma dönüşmektedir. İşin gerektirdiği biçimde, özel alanı biçimlendirme çabası, yeni ekonominin, çalışanlar üzerindeki kuşatıcı iktidarının, her alanı bir risk ortamına dönüştüren özelliğini göstermektedir. Çalışanın kendisinden beklenilen en üst düzeyde verimlilik koşulunu yaratamama kaygısı ve gerginliği, çalışanda, farklı türden kaygıların oluşmasına da neden olmakta ve bu da, özel yaşamı kötü etkilemektedir. Örneğin, çalışanların, sürekli işi düşünmek zorunda kaldıkları için, aile bireyleriyle ilişkilerini belli bir mesafede tuttukları ve onların psikolojik beklentilerine karşılık veremedikleri (Kart, 2010, 344) sonucu ortaya çıkmaktadır. Çalışanın içinde bulunduğu çalışma koşullarının, çalışan için bir risk 
ortamına dönüşmesi, çalışmanın, bütün zamana yayılmasını zorunlu kılmaktadır. Aynı zamanda, çalışmanın, kısa vadeye yönelen, potansiyel yeteneğe odaklanan, geçmiş deneyimleri geçmişte bırakan bir biçimde yapılandırılması ve çalışanın bütün bunları aşma problemi ile karşı karşıya bırakılması (Sennett, 2009, 11-12), çalışanın özel yaşam alanını, "iş" için ötelemesine yol açmaktadır. Yeni ekonominin çalışma ilişkilerine getirdiği düzenlemeler, özellikle, çalışanların sahip oldukları işe finansal bağımlılıklarının yüksek olduğu durumlarda, sahip olduğu olanakları kaybetmemek için daha fazla çaba harcamak ve performanslarını sürekli artırmak zorunda kalmaları biçiminde etkili olmaktadır. Çünkü performansa dayalı olarak, çalışanların ücret ve prim uygulamaları değișebilmekte, çalışanın iş güvenliğinin sürdürülmesinde, performans kriterleri esas alınmaktadır. Çalışma koşullarının bu niteliği, çalışanlarda iş stresini artırarak, uzun dönemde fiziksel ve psikolojik sağlık sorunlarına yol açmakta ve bu durum, çalışanların stres ve yorgunluğunu özel alanına ya da ailesine taşımasına neden olmaktadır.

Organizasyonların, çalışanlardan beklenilen verimliliği gerçekleştirmelerini koşul olarak sunmaları, çalışma süresi ile stres ve diğer sağlık sorunları arasındaki bağlantıyı ortaya koymaktadır. Uzun çalışma saatleri, özellikle profesyonel çalışanlarda, çalışmadığı zamanlarında da olumsuz sonuçlar doğurabilmektedir. Çalışma süresinin uzunluğu, çalışanların, işleri daha hızlı yapma, uzun saatler çalışma, 7/24 çalışma ya da teknolojinin sunduğu olanaklardan dolayı, her zaman, her yerde çalışma baskısı biçiminde, farklı türde baskıları deneyimlemelerine yol açmaktadır (Milliken, \& Dunn-Jensen, 2005, 46). Söz konusu baskılar ve çalışanın iş yoğunluğunun, aile ile ilgili olan özel etkinliklerini gerçekleştirmeleri önünde engel oluşturması, çalışanlarda stres ve gerginlik benzeri olumsuz durumların yaşanmasına neden olmaktadır. Son zamanlarda yapılan araştırmalar, evle ilgili sorumlulukları olan, evin ya da başka birinin bakımından sorumlu olan erkeklerin de, en az kadınlar kadar, belki çok daha ciddi boyutlarda stresi deneyimlediklerini ortaya koymaktadır (Kossek, \& Lambert, 2005, 8). Özelikle çocuk sahibi çalışanların bu konuda daha çok zorlandıkları ortaya çıkmıştır. The Work/Life adlı çalışma (Pocock, 2003), benzer içerikte sorunlara değinmektedir. Birçok Avustralyalının, samimiyet, cinsel aktivite ve fiziksel durum açısından, ilişkilerinin çok kötü durumda olduğunu ortaya koymaktadır (Edwards, \& Wajcman, 2005, 50).

Benzer olumsuz durumların üstesinden gelmeye çalışan bireylerin, iş için uyguladığ stratejik düşünme ve davranma biçimlerini, özel alanındaki bireylere de aktardığı gözlenmekte ve bu konuda yaşamındaki bireylerden anlayış ve sabır bekledikleri görülmektedir (Kart, 2010, 345). Yeni çalışma koşullarının, çalışanın mobilitesini içeren yapısı, "profesyonel işin artması, çalışma saatlerinin uzaması, işin karmaşıklaşan yapısı, hızlı üretim için yapılan baskı, bireylerin iş ve özel yaşamları arasında ikilemin yaşanması gibi” (Milliken, \& Dunn-Jensen, 2005, 44) sonuçlar doğurmaktadır. İşyerinde baskının en önemli nedenlerinden biri uzun çalışma saatleridir. Çalışmanın, uzun çalışma saatlerine yayılmasının nedenleri, çalışanların işverene bağ 1 llı̆̆ını göstermek, iş güvensizliğini hissetmek veya çalışanların çok fazla işleri ve bunları tamamlayacak kadar yeterli zamanlarının olmaması biçiminde (Giga, \& Cooper, 2005, 435) farklılık gösterebilmektedir.

Uzun çalışma saatleri, çalışanların, aileyle veya yakınlarıyla daha az vakit geçirmesine yol açmaktadır. Son zamanlardaki raporlar, çalışan yetişkinlerin \%90'ının aileleriyle yeterince vakit geçiremediklerine ilişkin endişelerini dile getirdiklerini (Sutton, \& Noe, 2005, 151) ortaya koymaktadır. İş stresinin özel alana taşınması, çalışanların birlikte oldukları insanlarla gerginlikler yaşamalarına neden olmaktadır. İş ve aile arasında yaşanan çatışmanın kaynağı, "özel alanda harcanması gereken zamanın, iş alanındaki beklentilerin karşılanabilmesi için, iş için ve iş alanında harcanmasıdır" (Milliken, \& Dunn-Jensen, 2005, 44). Çok sayıda kişiyle, patronlarıyla, meslektaşlarıyla, eş ve çocuklarıyla, etkileşim halinde olan çalışanların, iş ve aile arasındaki sınırlar arasında kordinasyonu sağlayamamaları, karmaşık durumlara ve özellikle de gerginliklere 
neden olabilmektedir. Örneğin iş yükündeki umulmadık artıştan doğan stresle baş etmek zor olabilmektedir. Ancak, hem ailevi görevlerle, hem de artan iş yüküyle aynı anda baş etmek çok daha zor olabilmektedir (Friede, \& Ryan, 2005, 193). Aile ve iş arasında ikilemde kalan çal1şanların, yaşanılan süreçle baş edebilmek için, antidepresan kullanma eğilimlerini arttırdıkları (Kart, 2010, 346), iş stresine özel alandaki gerginliklerin de eklenmesi ile çalışanların daha fazla ilaç desteğine ihtiyaç duydukları görülmektedir (Kart, 2010, 349). Birçok çalışma, motivasyonun ve iş memnuniyetindeki azalmanın, işteki güvensizliğin ve baskının stresi arttırdığını ortaya koymaktadır (Giga, \& Cooper, 2005, 435). İș ve aile alanlarına ait sınırların birbirine karışmasının sonucunda ortaya çıkan stres, psikolojik zorlanma, memnuniyetsizlik, endişe, huzursuzluk ve diğer olumsuz etkileri de içermektedir. Fiziksel zorlanma, yüksek tansiyon ve kolesterol, bağışıklık sisteminde bozukluk ve fiziksel sağlık problemlerini kapsamaktadır. Davranışsal zorlanma ise, sigara kullanımı, aşırı yemek yeme, işe gitmeme ve çok fazla doktora gitme durumları yaratmaktadır. Zorlanmanın uzun süre devam etmesi, kanser, ülser, kronik depresyon, hipertansiyon ve kalp hastalıkları gibi, zihinsel ve bedensel hastalıklara yol açmaktadır (Edwards, \& Rothbard, 2005, 218-219). Aynı zamanda, sürekli olarak hesaplanabilir bir amaç ve araç ilişkisi içerisinde hareket etmek, çalışan açısından, yaşamın iş dışındaki diğer alanlarını da, duygulardan arınmış, yapay ve sahte ilişkiler ağına dönüştürmektedir. Birey, iş yaşamı içerisinde profesyonel bir kimliğe ulaştıkça, yaşamın tümlüğü duygusundan uzaklaşmakta ve bireyselliğinin merkeziliğini keşfetmektedir. Bu da, narsistlik, benmerkezcilik, duygu yitimi, uç akılcılık tuzaklarına kapılma gibi, patolojik sorunları ortaya çıkarmaktadır (Aytaç, 2005, 3).

İş organizasyonunun esnekliğe dayalı yeni biçimlerinin, çalışanın iş yükünü ve sorumluluğunu daha fazla genişletmesinden kaynaklanan bu durumlar, çalışanların sosyal ilişkilerini de yine iş temeli üzerinde geliştirmelerine neden olmaktadır. Çalışanların, bağlı oldukları iş sektörüne göre, arkadaş çevrelerini ve ilişkilerini oluşturdukları, görüşme taleplerini ve kurdukları iletişimin içeriğini yine bağlı oldukları iş organizasyonlarının beklentileri bağlamında, yani yeni ekonominin amaç ve araç mantığı çerçevesinde, biçimlendirdikleri görülmektedir. Diğer taraftan, duygusallık, kendilik ve özerklik temeline dayalı olan özel yaşamın, işin gerektirdiği parametreler üzerinden yeniden biçimlendirilmesi, çalışanın özel yaşamında yer alan bireylere de, iş ortamındaki bireylere karşı sergilediği davranış biçimleri gibi, "organizasyonların rasyonalitesine dayalı davranış biçimleri" sergilemelerine neden olabilmektedir (Kart, 2010, 346-347). Bu durum, Greenhaus ve Parasuraman'ın (1999) da ifade ettikleri gibi, bir rolün içindeki tutumun, diğer bir role pozitif bir şekilde eklenmesi ya da bir roldeki deneyimlerin yaşamdaki diğer rolleri zenginleştiren bir kaynak olarak hizmet vermesi anlamına gelmektedir. Bireylerin bir alandan diğer alanlara taşıdığ tutum ve davranış biçimlerini, iş ve özel yaşam arasındaki entegrasyonu ortaya koymaktadır (Kossek, \& Lambert, 2005, 5). Çünkü çalışanın, iş ve özel yaşamı arasında kesin, katı ve net bir çizgi çizmesi halinde, performansı, maaşı ve terfisi konusunda, bir takım olumsuz sonuçlardan etkilenebilmektedir (Milliken, \& Dunn-Jensen, 2005, 44). Bu durumun özel alana yansıması, "mümkünse evli olmayan çalışanların" işe tercih edilmeleri ve özellikle kadınların çocuk yapmalarının işin verimliliğini düşüreceği kaygısıyla bu isteklerini ötelemeleri biçimindeki eğilimleri gündeme getirmektedir (Kart, 2010, 188-191). Esnek çalışma düzenlemelerindeki artış, çalışanlar için ev ve iş arasındaki sınırları bulanıklaştırdığı için (Kossek, \& Lambert, 2005, 6), bir süre sonra çalışanda insani ve ahlaki olan duygulara karşı duyarsızlaşmaya neden olabilmektedir. Süreç, çalışanların evliliğe bakış açılarını etkilemekte ve evliliğin işin verimliliğini olumsuz etkilediğini düşünerek, evlenmek düşüncesinden giderek uzaklaşabilmelerine neden olmaktadır. Yine aynı gerekçelerle, çalışanlar arasında "boşanma" eğilimlerinin de giderek artığı görülmektedir (Kart, 2010, 349). Buradan hareketle, çalışma alanı ve süresini giderek belirsiz kılan yeni çalışma koşullarının, çalışanların kendisiyle ve ailesiyle kurdukları ilişkiyi sorunlu hale getiren bir süreç olarak, "özel yaşam" alanına ait olan değerleri ve anlamlılıkları aşındırarak, özel yaşamın içeriğini dönüştürdüğünü belirtmek mümkündür. 


\section{Sonuç}

Özel hayata ait olan ilişki örüntüleri, esnek iş organizasyonları ile işin gerektirdiği biçimlerde yeniden esnek ilişki ağlarıyla örülmektedir. İş ve özel alan arasında sınırlar, bulanık hale getirilerek, çalışan üzerinde tahakkümün sınırları genişletilmektedir. Çalışanın, hayatın ekonomik olmayan alanlarına doğru işi kaydırmak zorunda kalması, çalışanın kendisine, evliliğe ve aileye ilişkin mantığı ve değerleri üzerinde olumsuz etkilere yol açabilmekte ve aileleri bölebilmektedir. Böylelikle, özel alan, küresel sermaye alanına ait olan ekonomik ilişkilerin kendini ürettiği bir alana dönüşmektedir. Sermayenin mantığının bütün yaşam alanları üzerinde etkin ve etkili olması, ekonomik merkezli olanla, özel olan arasındaki ilişkiyi sorunlu kılmakta, bu iki alan arasındaki farklılıkları ortadan kaldırmaktadır.

Sermaye etkinliklerinin, çalışanın özel alanındaki, sosyal ilişki ağları üzerinden de kendini yeniden üreten günümüzdeki yapısı, özel alanın özekliğini bir sorunsala dönüştürmektedir. Günümüzde ekonomik görünümün, birçok bakımdan kültürel ve siyasal unsurlara içkin olan boyutunun, giderek özel alanı da kuşatması, sermayenin, iktidarını "yaşamın bütün boyutları" üzerinde genişlettiğini göstermektedir. Özel hayatın sınırlarını sorgulamak, ancak sermayenin giderek her yerde var olma anlamında "mekânsızlaşan" özelliğinin dikkate alınmasıyla anlam kazanabilmektedir. Söz konusu sorgulama, çalışanlar açısından, çeşitli ve farklı gerilim ve çatışmaların varlığına ilişkin bir çerçeve sunmakta, iş sürecinin yapılandırılması süreci içerisinde, özel alanı da dönüştürmeye yönelik eğilimler, çalışanın özel alanındaki ilişki ağlarını sorunlu hale getirmektedir.

"Esneklik" ilkesine dayalı çalışma koşullarının, işgücünü parçalayan ve bireyselleştiren yapısı, çalışanı sadece iş ortamında değil, özel yaşamında da yalnızlaştırmakta ve yabancılaştırmaktadır. İşgücü piyasasında çalışanın işi ile geçici bağlılıklar kurmasına neden olan "kuralsızlı" ve "esneklik" ilkelerinin özel hayata yansımaları, kısa vadeli, yüzeysel ve kurgusal ilişkilerin yaygınlaşması biçiminde karşımıza çıkmaktadır. Bu, çalışanlar arasında boşanma eğilimlerinin artması ve evliliğin işin verimliliğini düşürdüğüne ilişkin kanıların yaygınlık kazanması biçiminde belirginleşmektedir. Çalışanların, performansa dayalı ücret, bireysel hizmet sözleşmeleri ve pazarlık sürecinin bireyselleştirilmesi gibi uygulamalarla karşılaşması, sevgi, dostluk gibi ekonomik rasyonaliteye dayalı olmayan çıkarsız ilişkiler alanından, dürüstlük, iyilik, kendi olmak, güven, sadakat ve çıkarsızlık gibi, kalıcı değer ve anlamları geçersiz hale getirmektedir. Bu durumun, çalışanın bütün sosyal ilişkilerine yaygınlaşması durumunda ise, fiziksel, psikolojik ve sosyal içerikli sorunları kaçınılmaz kılmaktadır. Hem çalışanı, hem de çalışanın aile yaşantısını ve yakın çevresini olumsuz etkileyen, esnek iş düzenlemeleri, özel alanı da, güvencesiz, belirsiz ve riskli bir ortama dönüştürmektedir.

\section{KAYNAKÇA}

Aytaç, Ö. (2005). "Modern Kurumların Doğası Üzerine Eleştirel Bir Yaklaşım”. Amme İdaresi Dergisi, $38 / 2,1-23$.

Bauman, Z. (1997). Özgürlük. Çev. Vasıf Erenus. İstanbul: Sarmal Yayınevi.

Bauman, Z. (2001). Parçalanmış Hayat: Postmodern Ahlâk Denemeleri. Çev. İsmail Türkmen. İstanbul: Ayrıntı Yayınevi.

Bauman, Z. (2005). Bireyselleşmiş Toplum. Çev. Yavuz Alogan. İstanbul: Ayrıntı Yayınları.

Edwards, J. R., \& Rothbard, N. P. (2005). "Work and Family Stress and Well-Being: An Integrative Model of Person-Environment Fit Within and Between the Work and Family Domains". Ed. Kossek, E. E., \& Lambert, S. J. Work and Life Integration, Organizational, Cultural, and Individual Perspectives, 211-243. London: Lawrence Erlbaum Associates.

Edwards, P., \& Wajcman, J. (2005). The Politics of Working Life. Oxford: Oxford Press. 
Friede, A., \& Ryan, A. M. (2005). "The Importance of the Individual: How Self Evaluations Influence the Work-Family Interface". Ed. Kossek, E. E., \& Lambert, S. J. Work and Life Integration, Organizational, Cultural, and Individual Perspectives, 193-211. London: Lawrence Erlbaum Associates.

Giga, S. I., \& Cooper, G. L. (2005). "The Development of Psychosocial Capital in Organizations: Implications for Work and Family Life". Ed. Kossek, E. E., \& Lambert, S. J. Work and Life Integration, Organizational, Cultural, and Individual Perspectives, 429-445. London: Lawrence Erlbaum Associates.

Gray, J. (2006). Küresel Yanılgılar. Çev. Zerrin Koltukçuoğlu. İstanbul: Etkileşim Yayınları.

Gorz, A. (2001). Yaşadı̆̆ımız Sefalet, Kurtuluş Çareleri. Çev. Nilgün Tutal. İstanbul: Ayrıntı Yayınları.

Jacobs, E. E. (2006). Projections of Labor Force and Employment by Industry and Occupation, Handbook of U.S Labor Statistic, Employment, Earnings, Prices, Productivity, and Other Labor Data. Bernan Press.

Kart, E. (2010). Nitelikli İşgücünün Küresel Trajedisi, Tıbbi Tanıtım Temsilcileri Üzerine Bir Araştırma. İstanbul: Kavim Yayıncılık.

Lambert, S. J., \& Waxman, E. (2005). "Organizational Stratification: Distributing Opportunities For Balancing Work and Personal Life”. Ed. Kossek E. E., \& Lambert, S. J. Work and Life Integration, Organizational, Cultural, and Individual Perspectives, 103-127. London: Lawrence Erlbaum Associates.

Lambert, S. J., \& Kossek, E. E. (2005), “Work-Family Scholarship Voice and Context”. Ed. Kossek E. E., \& Lambert, S. J. Work and Life Integration, Organizational, Cultural, and Individual Perspectives, 3-19. London: Lawrence Erlbaum Associates.

MacDermid, S. M. (2005). “(Re)Considering Conflict Between Work and Family”. Ed. Kossek E. E., \& Lambert, S. J. Work and Life Integration, Organizational, Cultural, and Individual Perspectives, 1941. London: Lawrence Erlbaum Associates.

Mendel, G. (2005). Bir Otorite Tarihi, Süreklilikler ve Değişiklikler. Çev. Işık Ergüden. İstanbul: İletişim Yayınları.

Milliken, F. J., \& Dunn-Jensen, L. M. (2005). "The Changing Time Demands of Managerial and Professional Work: Implications for Managing the Work-Life Boundary”. Ed. Kossek E. E., \& Lambert, S. J. Work and Life Integration, Organizational, Cultural, and Individual Perspectives, 4361. London: Lawrence Erlbaum Associates.

Sennett, R. (2005). Karakter Aşınması: Yeni Kapitalizmde İşin Kişilik Üzerindeki Etkileri. Çev. Barış Yıldırım. İstanbul: Ayrıntı Yayınları.

Sennett, R. (2009). Yeni Kapitalizmin Kültürü. Çev. Aylin Onacak., İstanbul: Ayrıntı Yayınları.

Sutton, K. L., \& Noe, R. A. (2005). "Family-Friendly Programs and Work-Life Integration: More Myth Than Magic?”. Ed. Kossek E. E., \& Lambert, S. J. Work and Life Integration, Organizational, Cultural, and Individual Perspectives, 151-171. London: Lawrence Erlbaum Associates.

Toksöz, G. (1999). Gelişmiş Ülkelerde İşsizlik Üzerine Güncel Tartışmalar. Ankara: İmaj Yayıncılık.

Wanberg, C., \& Müeller, K. J. D., \& Shi, K. (2001). "Job Loss and the Experience of Unemployment: International Research and Perspectives". Ed. Neil A., \& Deniz S. O., \& Handan K. S. Handbook of Industrial, Work and Organizational Psychology 2, 253-273. London: SAGE Publications. 